\title{
Assessment of Knowledge, Attitude and Practice on Prevention of Catheter-associated Urinary Tract Infection (CAUTI) among Health Care Professionals Working in a Tertiary Care Teaching Hospital
}

\author{
Pandian Balu ${ }^{1}$ (D) , Divya Ravikumar ${ }^{2}$ D , Virudhunagar Muthuprakash \\ Somasunder $^{3}\left(\mathbb{D}\right.$, Sumetha Suga Deiva Suga ${ }^{3}$ (D) , Poonguzhali Sivagananam ${ }^{1}$ \\ (D) , Vasantha Priya Jeyasheelan ${ }^{1}$ (D) , Radhika Nalinakumari Sreekandan ${ }^{4}$, \\ Kavin Mozhi James ${ }^{1} \mathbb{D}$, Savithri Kanganda Bopaiah ${ }^{1}$, Udayakumari Meesala \\ Chelladurai $^{1}{ }^{(D)}$, Manuel Raj Kumar ${ }^{5}$ iD , Poongodi Chellapandian ${ }^{6}{ }^{D}$, Narmatha \\ Sundharesan ${ }^{7}$ (D) Mythili Krishnan ${ }^{8}$ id , Vahithamala Kunasekaran ${ }^{8}$ (D) , Kayalvizhi \\ Kumaravel $^{9}$ (D) , Rejili Grace Joy Manickaraj ${ }^{9}$ (D) , Vishnu Priya Veeraraghvan ${ }^{10}$ (D) \\ and Surapaneni Krishna Mohan ${ }^{11 *}$ (D)
}

\footnotetext{
${ }^{1}$ Department of Medical Surgical Nursing, Panimalar College of Nursing, Varadharajapuram, Poonamallee, Chennai - 600 123, Tamil Nadu, India.

2Department of Obstetrics \& Gynaecology, Panimalar Medical College Hospital \& Research Institute, Varadharajapuram, Poonamallee, Chennai - 600 123, Tamil Nadu, India.

${ }^{3}$ Department of Microbiology, Panimalar Medical College Hospital \& Research Institute, Varadharajapuram, Poonamallee, Chennai - 600 123, Tamil Nadu, India.

${ }^{4}$ Department of Clinical Skills \& Simulation, Panimalar Medical College Hospital \& Research Institute, Varadharajapuram, Poonamallee, Chennai - 600 123, Tamil Nadu, India.

${ }^{5}$ Hospital Infection Control Nurse, Panimalar Medical College Hospital \& Research Institute, Varadharajapuram, Poonamallee, Chennai - 600 123, Tamil Nadu, India.

${ }^{6}$ Department of Obstetrics \& Gynaecological Nursing, Panimalar College of Nursing, Varadharajapuram, Poonamallee, Chennai - 600 123, Tamil Nadu, India.

${ }^{7}$ Department of Child Health Nursing, Panimalar College of Nursing, Varadharajapuram, Poonamallee, Chennai - 600 123, Tamil Nadu, India.

${ }^{8}$ Department of Community Health Nursing, Panimalar College of Nursing, Varadharajapuram, Poonamallee, Chennai - 600 123, Tamil Nadu, India.

${ }^{9}$ Department of Mental Health Nursing, Panimalar College of Nursing, Varadharajapuram, Poonamallee, Chennai - 600 123, Tamil Nadu, India.

${ }^{10}$ Department of Biochemistry, Saveetha Dental College \& Hospital, Saveetha Institute of Medical \& Technical Sciences (SIMATS), Saveetha University, Velappanchavadi, Chennai - 600 077, Tamil Nadu, India.

${ }^{11}$ Department of Biochemistry, Department of Clinical Skills \& Simulation, and Department of Research, Panimalar Medical College Hospital \& Research Institute, Varadharajapuram, Poonamallee, Chennai - 600123 , Tamil Nadu, India.
}

*Correspondence: krishnamohan.surapaneni@gmail.com (Received: June 25, 2020; accepted: December 26, 2020) Citation: Balu P, Ravikumar D, Somasunder VM et al. Assessment of Knowledge, Attitude and Practice on Prevention of Catheterassociated Urinary Tract Infection (CAUTI) among Health Care Professionals Working in a Tertiary Care Teaching Hospital. J Pure App/ Microbiol. 2021; 15(1):335-345. doi:10.22207/JPAM.15.1.28

(C) The Author(s) 2021. Open Access. This article is distributed under the terms of the Creative Commons Attribution 4.0 International License which permits unrestricted use, sharing, distribution, and reproduction in any medium, provided you give appropriate credit to the original author(s) and the source, provide a link to the Creative Commons license, and indicate if changes were made. 


\begin{abstract}
Catheter-associated Urinary Tract Infection (CAUTI) is a common healthcare-related infection occurring in patients admitted for various ailments. Approximately $80 \%$ of hospital acquired Urinary Tract Infections (UTIS) are catheter associated. The purpose of the current research was to find out the level of knowledge, attitude and practice on prevention of CAUTI among healthcare professionals working in tertiary care hospital. A descriptive study was done among 95 health care working in tertiary care hospital in Chennai. The researchers administered standard questionnaire and statistically explored the knowledge, attitude, and practice levels about prevention of CAUTI among the participants. Among 95 participants, $\mathbf{2 8 . 4 \%}$ and $\mathbf{7 1 . 6 \%}$ of the individuals had moderately adequate knowledge and adequate knowledge about CAUTI. About $4.2 \%$ of the participants had unfavourable, $88.4 \%$ had moderately favourable and $7.4 \%$ had favourable attitude towards prevention of CAUTI. About $4.2 \%$ of the individuals had moderately adequate and $95.8 \%$ had adequate practice towards the prevention of CAUTI. There was significant correlation between attitude and practice. The professional experience of the participants showed statistically significant association with the level of practice among the demographic variables. In our present study, we found out that health care professionals had adequate knowledge, attitude, and practice on prevention of CAUTI. Medical education programs, frequent auditing with a checklist about catheter care must be conducted to maintain the achieved knowledge and practice levels.
\end{abstract}

Keywords: Knowledge, Attitude, Practice, Health care professionals, CAUTI, Prevention

\section{INTRODUCTION}

Urinary catheterization is an indispensable procedure performed in hospitals especially, in ICU settings. Approximately $70-80 \%$ of all acquired UTIs are due to improper urinary catheterization and failure to follow the Centres for Disease Control (CDC) guidelines for catheterization ${ }^{1}$.

CAUTI is the most common and frequently occurring nosocomial infection in patients admitted with hip fracture, spinal cord injury, urinary incontinence, bladder obstruction and extended use of indwelling catheterization in chronically sick patients ${ }^{1}$. Urinary Tract Infection affects 150 million people worldwide and approximately $80 \%$ of the nosocomial UTIs are catheter associated ${ }^{1}$. CAUTI is caused by variety of pathogens including Escherichia coli, followed by Proteus species and Pseudomonas species. The other causative microbial organisms are Enterococci, Klebsiella, Candida, Serratia and few others ${ }^{1}$. CAUTI shows clear female predominance due to the anatomy of the urinary tract and the hormonal changes that take place in women. The possibilities for developing bacteriuria and UTI are seen in geriatric and paediatric age group, impaired immunity, comorbid conditions like diabetes, hypertension, and obesity ${ }^{2}$.

According to World Health Organization (WHO), infections acquired by patients during the period of hospital stay is a major public health concern which may leads to increase in duration of the patient's hospital stay, rise in the morbidity and mortality rate, financial burden, and causes additional sufferings for their family members. ${ }^{3,4}$ More than one-fourth of all hospital in-patients will be catheterized during their hospital stay, due to various reasons ${ }^{5}$. CAUTI may lead to many physical complaints in admitted patient such as fever, body pain, and prolonged antibiotic intake leading to the development of multidrug resistant pathogens. For those developing drug resistant organisms, urinary tract acts as a reservoir and can be spread to other nearby patients ${ }^{6}$.

Majority of CAUTI are preventable. By following proper guidelines and preventive measures such as washing hands effectively by using appropriate techniques, meticulous care of the indwelling catheter and proper removal of the catheter CAUTI can be prevented. Unnecessary urinary catheterization and the prolonged duration of catheterization should be avoided. Evidence based practices need to be followed in order to improve patient care?

Catheter insertion and its care is the cornerstone for the prevention of CAUTI. However, applying and following the needed preventive measures may be challenging in busy clinical settings ${ }^{8}$. Therefore this study was undertaken with 
the target to investigate the depth of knowledge, attitude, and practice on prevention of CAUTI among Healthcare Professionals (HCPs) in a tertiary hospital in Chennai.

\section{MATERIALS AND METHODS Study participants}

This present study was a cross-sectional study carried out in Tamil Nadu, India. A semistructured questionnaire developed by the researchers was used to assess the Knowledge, Attitude and Practice levels on prevention of CAUTI among health care professionals working in a tertiary care hospital. The sample was collected through random sampling technique.

\section{Inclusion criteria}

- Age criteria - 21 years and above

- Individuals who are working in health care sectors

- Individuals who are willing to participate in the study

Exclusion criteria

- Individuals those who are not willing to participate in the study.

- Incomplete questionnaire form

A total of 130 participants were involved in the research. Only 95 participants completed the research questionnaire.

\section{Compliance with Ethical Standards}

The research was initiated after obtaining the approval from Institute of Research board of Panimalar Medical College Hospital \& Research Institute, Chennai. (IRB\#1/2020/014). Data collected from the participants were kept confidential.

\section{Data collection tools}

A validated structured questionnaire on knowledge and modified Likert scaled attitude, and practice questionnaire were given to the participants for assessment. It was framed by following the review of literatures, national, and international CDC guidelines. The questionnaire was validated by following face validity method. The validity and reliability of the tool were tested by conducting a pilot study in different group of participants working in tertiary care hospital. The participants involved in the pilot study were not included in the present study.

\section{Methods of measurement (Scoring)}

The questionnaire consisted of four sections. The demographic data section, it consists of details of the participants such as age, gender, education, profession, and professional experience. This was followed by a set of 14 , yes or no questions to assess the level of knowledge. Score of " 1 " was awarded to the correct response and " 0 " was awarded to the incorrect response accordingly. The possible total knowledge score could range from 0 to 14 . Based on the mean score, the level of knowledge was classified into inadequate, moderately adequate, and adequate knowledge, if the score was below, equal and more than the mean score. The section to assess attitude comprised of 8 statements which was scaled by using 5 points Likert scale. Options for the provided positive statements were "Strongly Agree," "Agree," "Neither agree nor disagree," "Disagree," and "Strongly disagree" and was given score from 1 to 5 , respectively. The scores were reversely coded as 5, 4, 3, 2, and 1, for negatively phrased questions. Then, the overall attitude score was calculated, which could range from 8 to 40 . Attitude scores 'below the mean' was assigned for unfavourable attitude section, 'above the mean score' were assigned for favourable attitude section, and 'equal to the mean score' were classified under moderately favourable attitude section. The final sections for practice assessment had a set of 10 statements which were scaled by 3 point scale. Options for the provided positive statements were "Agree," "Neither agree nor disagree," and "Disagree," scored from 1 to 3 , as stated. The scores were reversely coded as three, two, one, for negatively phrased questions. Then, total overall score calculated, ranged from 10 to 30. Practice scores were categorized into three sections - inadequate practice, moderately adequate practice, and adequate practice. The below mean score was categorized into inadequate practice, above mean score was categorized into adequate practice, and equal to mean score was assigned for moderately adequate practice section.

\section{Statistical Analysis}

SPSS (Statistical Package for Social Sciences) software for Microsoft windows- 17 was 
used to calculate the statistics. Cross tabulation was used for calculating descriptive statistical data.

\section{RESULTS}

Based on the inclusion and exclusion criteria, 130 participants were included in the study. Out of which 95 participants submitted the completed questionnaires. Table 1, illustrates the demographic variables of health care professionals. About $10.5 \%$ belonged to the age group of above 21-24 years, between 25-30 years of age was $65.3 \%$, and participants of more than 30 years were $24.2 \%$. Among the participants $69.5 \%$ were females and $30.5 \%$ were male. About $49.5 \%$ were doctors, $48.4 \%$ were nurses, and $2.1 \%$ were other allied health care professionals in our study. About $27.4 \%$ were diploma holders, undergraduate were $45.3 \%$, and postgraduates were $27.4 \%$ among the study population. Participants with professional experience less than 6 months were 35.8\%, 6 months -2 years were $25.3 \%$, professionals with 2- 6 years of experience were 16.8\%, 7-10 years of experience were $10.5 \%$, and participants with more than 10 years of experience were $11.6 \%$.

Table 1. Demographic characteristics of health care professionals $(n=95)$

\begin{tabular}{|c|c|c|}
\hline Demographic variables & Frequency & Percentage \\
\hline Age & $\mathrm{n}$ & $\%$ \\
\hline 21-24 Years & 10 & $10.5 \%$ \\
\hline 25 - 30 Years & 62 & $65.3 \%$ \\
\hline > 30 Years & 23 & $24.2 \%$ \\
\hline \multicolumn{3}{|l|}{ Gender } \\
\hline Female & 66 & $69.5 \%$ \\
\hline Male & 29 & $30.5 \%$ \\
\hline \multicolumn{3}{|l|}{ Profession } \\
\hline Medicine & 47 & $49.5 \%$ \\
\hline Nursing & 46 & $48.4 \%$ \\
\hline Allied Health Sciences & 2 & $2.1 \%$ \\
\hline \multicolumn{3}{|l|}{ Educational qualification } \\
\hline Diploma & 26 & $27.4 \%$ \\
\hline Undergraduate & 43 & $45.2 \%$ \\
\hline Post Graduate & 26 & $27.4 \%$ \\
\hline \multicolumn{3}{|l|}{ Professional Experience } \\
\hline Less than 6 Months & 34 & $35.8 \%$ \\
\hline 6 Months - 2 Years & 24 & $25.3 \%$ \\
\hline 2 - 6 Years & 16 & $16.8 \%$ \\
\hline 7 - 10 Years & 10 & $10.5 \%$ \\
\hline More than 10 Years & 11 & $11.6 \%$ \\
\hline
\end{tabular}

\section{Knowledge on CAUTI}

The knowledge level assessment of the research participants, are shown in Table 2, 28.4\% ( $n=27$ ) of individuals had moderately adequate knowledge and $71.6 \%(n=68)$ had adequate knowledge about CAUTI. Average mean knowledge of the study participants was $11.42 \pm 1.534$ (Table 2). $82.1 \%$ of the research participants were aware that CAUTI is one of the hospital acquired infection, $94.7 \%$ of the participants were aware that high risk groups for CAUTI include female gender and elderly patients, $95.8 \%$ of the research participants knew that strict aseptic precautions to be followed for urinary catheterization to prevent the CAUTI among the catheterised patients, $78.9 \%$ of the research participants were aware that as per the CDC guidelines, the catheter must be removed within 24 hours for the post-operative patients, $92.6 \%$ of the participants aware that cleaning the peri-urethral region with antiseptics is mandatory to prevent CAUTI, $94.7 \%$ of the participants aware that securing the IUC catheter properly after insertion, is important to prevent displacement of the catheter and injury to the bladder, $84.2 \%$ participants aware that CAUTI increases the duration of the patient's stay in the hospital, $94.7 \%$ of the participants know that if the urinary catheter remains indwelling for a month, the risk of bacteriuria is high, $70.5 \%$ of the participants were aware that cleaning of the meatus and catheter with soap and water daily will reduce the possibility of CAUTI (Table 3).There was no correlation between the level of knowledge with attitude, practice (Table 4). There was no significant association of age, gender, profession, education, and professional years of experience in health care professional with the level of knowledge among the research participants (Table 5).

\section{Attitude towards CAUTI}

In this present study, as illustrated in Table 2, 4.2\% ( $n=4)$ had unfavourable attitude, $88.4 \%(n=84)$ had moderately favourable attitude and $7.4 \%(n=7)$ had favourable attitude towards CAUTI. Average mean and standard deviation of the attitude of the research participants was $26.01 \pm 2.793$ (Table.2). About 51.6\% research participants agreed that renewal reminders for catheter, prevents CAUTI, $55.8 \%$ of the participants strongly agreed that education 
and training regarding basic catheter care, will help in prevention of CAUTI. About $55.8 \%$ of the participants agreed that routine screening for asymptomatic bacteriuria is recommended in catheterized patients (Table 4). There was correlation between the levels of attitude with

Table 2. Level of Knowledge, Attitude, and Practice on prevention of CAUTI among health care professionals. ( $n=95)$

\begin{tabular}{lccccc}
\hline Variables & Levels & Frequency & Percentage & Mean & SD \\
\hline $\begin{array}{l}\text { Knowledge of health care } \\
\text { professionals on CAUTI }\end{array}$ & $\begin{array}{c}\text { Moderately adequate } \\
\text { knowledge }\end{array}$ & 27 & 28.4 & 11.42 & 1.534 \\
Adequate knowledge & 68 & 71.6 & & \\
Attitude of health care & $\begin{array}{c}\text { Unfavourable Attitude } \\
\text { professionals on CAUTI }\end{array}$ & 4 & 4.2 & 26.01 & 2.973 \\
& $\begin{array}{c}\text { Moderate favourable } \\
\text { Attitude }\end{array}$ & 84 & 88.4 & & \\
Practice of prevention of & $\begin{array}{c}\text { Favourable Attitude } \\
\text { ModeratePractice }\end{array}$ & 7 & 7.4 & 26.71 & 1.967 \\
health care professionals & Adequate Practice & 91 & 95.8 & & \\
\hline on CAUTI & & & & &
\end{tabular}

Table 3. Assessment of Knowledge on CAUTI among health care professionals ( $n=95$ )

\begin{tabular}{|c|c|c|c|c|c|}
\hline \multirow[t]{2}{*}{ Q.No } & \multirow[t]{2}{*}{ Variables } & \multicolumn{2}{|c|}{ Yes } & \multicolumn{2}{|c|}{ No } \\
\hline & & $\mathrm{n}$ & $\%$ & $\mathrm{n}$ & $\%$ \\
\hline 8 & $\begin{array}{l}\text { Most common Hospital acquired infection is } \\
\text { CAUTI }\end{array}$ & 78 & 82.1 & 17 & 17.9 \\
\hline 9 & $\begin{array}{l}\text { Risk factor of CAUTI is not directly related to the } \\
\text { duration of catheterization }\end{array}$ & 36 & 37.9 & 59 & 62.1 \\
\hline 10 & $\begin{array}{l}\text { High risk groups for CAUTI include female } \\
\text { gender and elderly patients }\end{array}$ & 90 & 94.7 & 5 & 5.3 \\
\hline 11 & $\begin{array}{l}\text { Acute urinary retention and bladder obstruction } \\
\text { is the indication catheterization }\end{array}$ & 85 & 89.5 & 10 & 10.5 \\
\hline 12 & $\begin{array}{l}\text { Strict Aseptic precautions to be followed for } \\
\text { urinary catheterization }\end{array}$ & 91 & 95.8 & 4 & 4.2 \\
\hline 13 & $\begin{array}{l}\text { Catheter must be removed as soon as possible } \\
\text { or within } 24 \text { hours for catheterized post- } \\
\text { operative patients. }\end{array}$ & 75 & 78.9 & 20 & 21.1 \\
\hline 14 & $\begin{array}{l}\text { Cleaning the peri-urethral region with antiseptics } \\
\text { is mandatory to prevent CAUTI }\end{array}$ & 88 & 92.6 & 7 & 7.4 \\
\hline 15 & $\begin{array}{l}\text { Secure the IUC catheter properly after insertion, } \\
\text { to prevent displacement of the catheter and } \\
\text { injury to the bladder }\end{array}$ & 90 & 94.7 & 5 & 5.3 \\
\hline 16 & $\begin{array}{l}\text { CAUTI increases the duration of the patient's } \\
\text { stay in the hospital }\end{array}$ & 80 & 84.2 & 15 & 15.8 \\
\hline 17 & $\begin{array}{l}\text { If urinary catheter remains indwelling for a } \\
\text { month, the risk of bacteriuria is high }\end{array}$ & 90 & 94.7 & 5 & 5.3 \\
\hline 18 & $\begin{array}{l}\text { silicone alloy-coated indwelling urinary catheters } \\
\text { may benefit the patients for long-term-care }\end{array}$ & 82 & 86.3 & 13 & 13.7 \\
\hline 19 & $\begin{array}{l}\text { Frequent use of lubricants with antiseptics may } \\
\text { not be necessary }\end{array}$ & 44 & 46.3 & 51 & 53.7 \\
\hline 20 & $\begin{array}{l}\text { Daily cleaning of the meatus and catheter with } \\
\text { soap and water reduce the possibility of CAUTI }\end{array}$ & 67 & 70.5 & 28 & 29.5 \\
\hline 21 & CAUTI is most often caused by Escherichia coli & 88 & 92.6 & 7 & 7.4 \\
\hline
\end{tabular}


Table 4. Assessment of Attitude towards prevention of CAUTI among health care professionals $(n=95)$

\begin{tabular}{|c|c|c|c|c|c|c|c|c|c|c|c|}
\hline \multirow[t]{2}{*}{ Q.No } & \multirow[t]{2}{*}{ Variables } & \multicolumn{2}{|c|}{$\begin{array}{l}\text { Strongly } \\
\text { agree }\end{array}$} & \multicolumn{2}{|c|}{ Agree } & \multicolumn{2}{|c|}{$\begin{array}{l}\text { Neither } \\
\text { agree nor } \\
\text { disagree }\end{array}$} & \multicolumn{2}{|c|}{ Disagree } & \multicolumn{2}{|c|}{$\begin{array}{l}\text { Strongly } \\
\text { disagree }\end{array}$} \\
\hline & & $\mathrm{n}$ & $\%$ & $\mathrm{n}$ & $\%$ & $\mathrm{n}$ & $\%$ & $\mathrm{n}$ & $\%$ & $\mathrm{n}$ & $\%$ \\
\hline 22 & $\begin{array}{l}\text { Renewal reminders for } \\
\text { catheter prevents CAUTI }\end{array}$ & 34 & 35.7 & 49 & 51.6 & 9 & 9.5 & 2 & 2.1 & 1 & 1.1 \\
\hline 23 & $\begin{array}{l}\text { Development of CAUTI } \\
\text { cannot be avoided among } \\
\text { catheterized patients. }\end{array}$ & 16 & 16. 8 & 28 & 29.5 & 17 & 17. 9 & 24 & 25.3 & 10 & 10. 5 \\
\hline 24 & $\begin{array}{l}\text { CAUTI is not a very serious } \\
\text { illness. }\end{array}$ & 8 & 8.4 & 26 & 27.5 & 16 & 16.8 & 37 & 38.9 & 8 & 8.4 \\
\hline 25 & $\begin{array}{l}\text { Education regarding basic } \\
\text { catheter care helps to prevent } \\
\text { CAUTI }\end{array}$ & 53 & 55.8 & 36 & 37.8 & 5 & 5.3 & 0 & 0 & 1 & 1.1 \\
\hline 26 & $\begin{array}{l}\text { Health care workers can } \\
\text { remove the catheter } \\
\text { whenever they are convenient }\end{array}$ & 17 & 17.9 & 27 & 28.4 & 7 & 7.4 & 35 & 36.8 & 9 & 9.5 \\
\hline 27 & $\begin{array}{l}\text { Prevention of CAUTI is a } \\
\text { frequent problem and } \\
\text { impossible to attain it }\end{array}$ & 11 & 11.6 & 22 & 23.2 & 14 & 14.7 & 37 & 38.9 & 11 & 11.6 \\
\hline 28 & $\begin{array}{l}\text { Aseptic precautions may not } \\
\text { be needed for removing the } \\
\text { Foley's catheter }\end{array}$ & 10 & 10.5 & 24 & 25.3 & 11 & 11.6 & 36 & 37.9 & 14 & 14. 7 \\
\hline 29 & $\begin{array}{l}\text { Routine screening for } \\
\text { asymptomatic bacteriuria } \\
\text { (ASB) is recommended in } \\
\text { catheterized patients, which } \\
\text { has now not advised by the } \\
\text { CDC prior to catheter insertion }\end{array}$ & 26 & 27.3 & 53 & 55.8 & 7 & 7.4 & 7 & 7.4 & 2 & 2.1 \\
\hline
\end{tabular}

practice (Table 6). The attitude level of the participants towards CAUTI prevention had no statistically significance with the selected demographic variables (Table 5).

\section{Practice on Prevention of CAUTI}

Among the 95 research participants, $4.2 \%$ ( $n=4)$ of individuals had moderate practice, and $95.8 \%(n=91)$ had adequate practice on prevention of CAUTI. Average mean and standard deviation of the practice level of the research participants was $26.71 \pm 1.967$ (Table 2). About $96.8 \%$ of the research participants were aware that before and after handling of the catheter site, hands must be washed with antiseptics. $93.7 \%$ of the participants were aware that appropriate catheter size should be used to minimize urethral trauma, $89.5 \%$ were aware that kinking or twisting of the catheter must be prevented for unobstructed flow of urine,
94.7\% of the participants were aware that the urine collecting bag should be emptied regularly and must be kept below the bladder level (Table $5)$. There was correlation between the levels of practice with attitude but there was no correlation with knowledge (Table 4). Professional experience had statistically significant association with the level of practice among the demographic variables at $p=0.01$ and other demographic variables like age, gender, profession, education in health care professional showed statistically no significant relationship. (Table 7)

\section{DISCUSSION}

For many decades lot of research and practice guidelines have been devised to determine the effective strategies for avoiding indwelling urethral Catheterization (IUC) and 
Table 5. Assessment of Practice on prevention of CAUTI among health care professionals ( $n=95$ )

\begin{tabular}{|c|c|c|c|c|c|c|c|}
\hline \multirow[t]{2}{*}{ Q.No } & \multirow[t]{2}{*}{ Variables } & \multicolumn{2}{|c|}{ Agree } & \multicolumn{2}{|c|}{$\begin{array}{l}\text { Neither } \\
\text { agree nor } \\
\text { disagree } \\
\end{array}$} & \multicolumn{2}{|c|}{ Disagree } \\
\hline & & $\mathrm{n}$ & $\%$ & $\mathrm{n}$ & $\%$ & $\mathrm{n}$ & $\%$ \\
\hline 30 & $\begin{array}{l}\text { Before and after handling the catheter site, } \\
\text { hands must be washed with antiseptics. }\end{array}$ & 92 & 96.8 & 2 & 2.1 & 1 & 1.1 \\
\hline 31 & $\begin{array}{l}\text { Appropriate catheter size should be used to } \\
\text { minimize urethral trauma }\end{array}$ & 89 & 93.6 & 5 & 5.3 & 1 & 1.1 \\
\hline 32 & $\begin{array}{l}\text { Urinary Catheterization must be done } \\
\text { whenever there is an appropriate indication. }\end{array}$ & 82 & 86.3 & 9 & 9.5 & 4 & 4.2 \\
\hline 33 & $\begin{array}{l}\text { Twisting and kinking of the catheter must be } \\
\text { prevented for an unobstructed flow of urine }\end{array}$ & 85 & 89.5 & 6 & 6.3 & 4 & 4.2 \\
\hline 34 & $\begin{array}{l}\text { At least once daily, the bladder must be } \\
\text { irrigated with antimicrobial solutions/iodine } \\
\text { solution. }\end{array}$ & 52 & 54.7 & 20 & 21.1 & 23 & 24.2 \\
\hline 35 & $\begin{array}{l}\text { urine collection bag should be emptied } \\
\text { regularly }\end{array}$ & 90 & 94.7 & 4 & 4.2 & 1 & 1.1 \\
\hline 36 & $\begin{array}{l}\text { Urine collection bag must be positioned and } \\
\text { fixed below the level of the bladder }\end{array}$ & 90 & 94.7 & 3 & 3.2 & 2 & 2.1 \\
\hline 37 & $\begin{array}{l}\text { Isolation must be done for a patient with UTI, } \\
\text { from other non-infected patients }\end{array}$ & 28 & 29.5 & 31 & 32.6 & 36 & 37.9 \\
\hline 38 & $\begin{array}{l}\text { Maintaining close drainage system prevents } \\
\text { CAUTI }\end{array}$ & 65 & 68.4 & 18 & 18.9 & 12 & 12.7 \\
\hline 39 & $\begin{array}{l}\text { Regular educational training to be given on } \\
\text { basic urinary catheter care }\end{array}$ & 90 & 94.7 & 5 & 5.3 & 0 & 0 \\
\hline
\end{tabular}

to prevent its related complications such as prolonged usage, decubitus ulcer, and hospitalacquired infections. In general, most of these interventions were aimed at changing the beliefs and behaviours of health care professionals towards CAUTI as well as concerning limited usage of IUC and safe management of IUC ${ }^{9}$. Every hospital should adopt strict infection control measures to minimize the occurrence of CAUTI.
In our present study, Among 95 participants, $65.3 \%$ of the health care professionals belonged to the age group of more than 30 years. About $69.5 \%$ were female participants which were similar to the study done by Assanga et al. ${ }^{10}$ Equal percentage of doctors and nurses has participated in our study. Among them, 45.3\% were under graduates with $11.6 \%$ having more than 10 years of experience.

Table 6. Correlation between knowledge, attitude and practice on prevention of CAUTI among healthcare professionals ( $n-95)$

\begin{tabular}{lllll}
\hline \multicolumn{2}{l}{ Spearman's correlation rho } & Knowledge & Attitude & Practice \\
\hline \multirow{2}{*}{ Knowledge } & Correlation Coefficient & 1.000 & 0.072 & 0.058 \\
& Sig. (2-tailed) & 0 & 0.488 & 0.579 \\
\multirow{2}{*}{ Attitude } & Correlation Coefficient & 0.072 & 1.000 & $0.264^{* *}$ \\
\multirow{4}{*}{ Practice } & Sig. (2-tailed) & 0.488 & 0 & 0.010 \\
& Correlation Coefficient & 0.058 & $0.264^{* *}$ & 1.000 \\
& Sig. (2-tailed) & 0.579 & 0.010 & 0 \\
\hline
\end{tabular}

The correlation is significant ** At $\mathrm{P}<0.01$ level (2-tailed). 


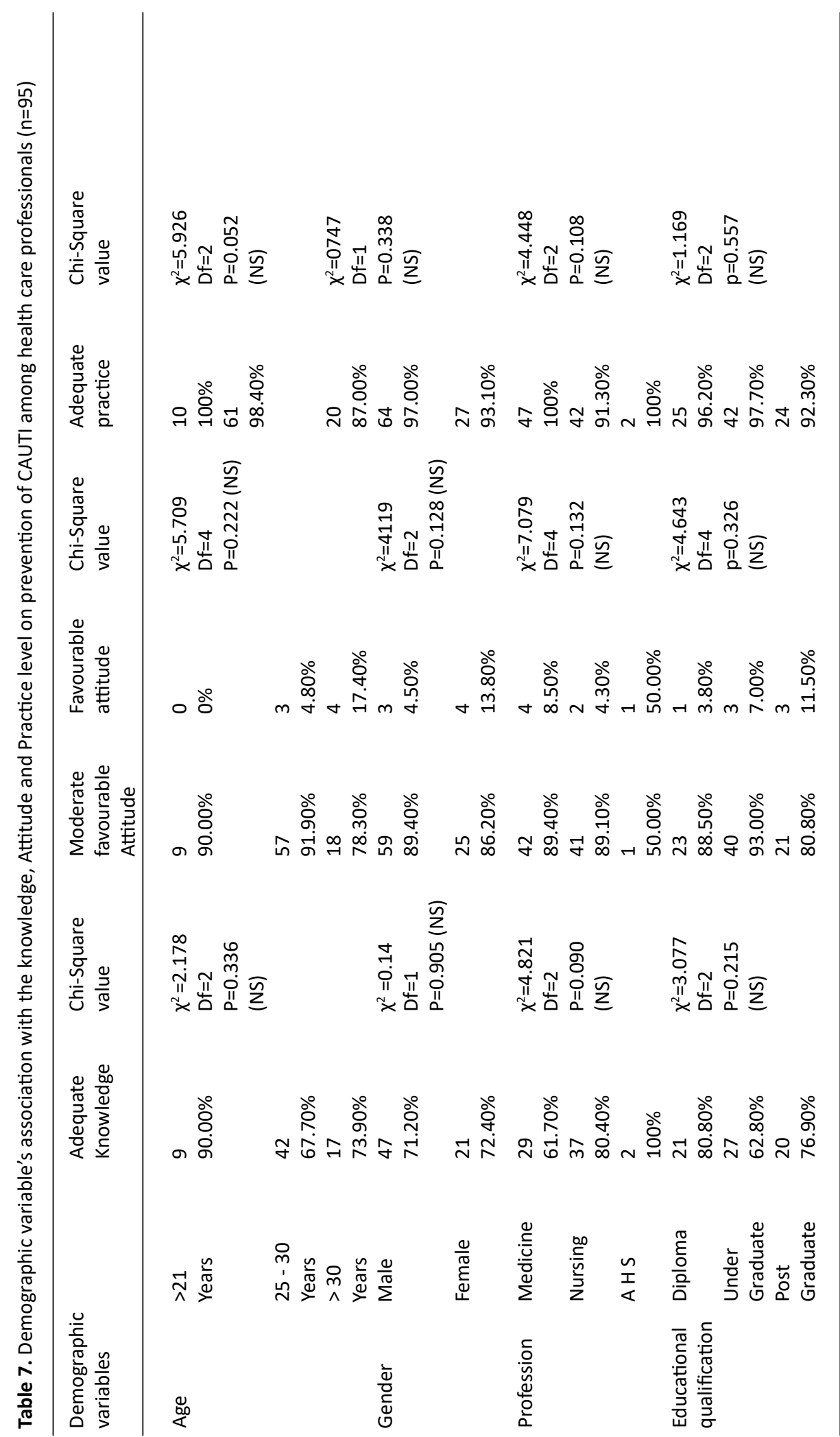

Journal of Pure and Applied Microbiology 


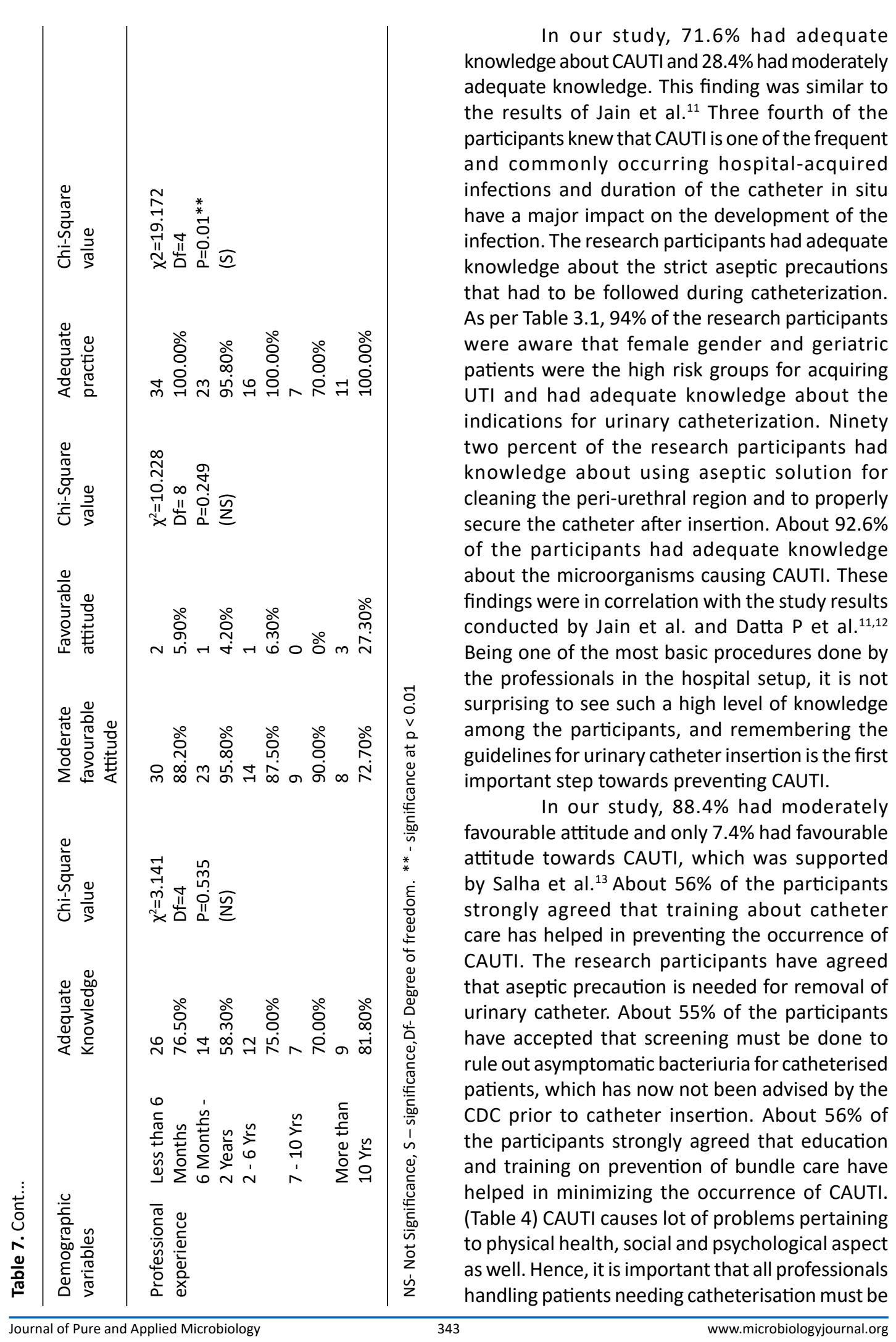


aware of the updated and revised guidelines. In our study, $95.8 \%$ of the research participants had adequate practice and only $4.2 \%$ needed more training and practice sessions for improvement of their skills in handling CAUTI. The study group had adequate practice towards washing hands before and after handling the catheter (Table 5). About $86 \%$ of the professionals follow the guidelines for the need for catheterisation and removal of the catheter. Our study participants have practiced effective catheter care for preventing CAUTI by maintaining a close drainage system, isolating the UTI patients, keeping urinary bag below the bladder level and emptying the urinary collection bag regularly. These findings were supported by Menegueti et al and Parker et al. ${ }^{8,14}$

There was a correlation between attitude and practice ( $A-P)$ as calculated by spearman's correlation at $\mathrm{P}<0.01$ level (2-tailed). Current research showed a significant association between professional experience and practice at $p<0.01$ (Table 7). There was no significant association between the other demographic variable with knowledge, practice and attitude. This may be attributed to the trainings given of the professionals to meticulously follow protocol and hence over the years, their practice towards CAUTI has improved.

Our results obtained from this study reflects the importance of setting up guidelines and policies to support the prevention of CAUTI. There must be sufficient staffing, educational training sessions, and access to adequate and appropriate supplies. Proper documentation for the urinary catheter use, indication for catheterization, date of insertion and removal, should be maintained and established. ${ }^{15}$

\section{CONCLUSION}

CAUTI is one of the most frequently occurring healthcare acquired infections. In the current study, health care professionals had adequate knowledge, attitude, and practice on prevention of CAUTI. Infection prevention programs in every hospital must develop, implement, and monitor policies and procedures to minimize infections associated with the use of urinary catheters. In the health care setups, there must be medical education programs, interdisciplinary training programs, and audits to be conducted with checklist about catheter care to improve the knowledge and practice of health care professionals.

\section{Statement of limitations}

The Sample size was small, as many participants were not be able to include in the study due to the COVID-19 pandemic, hence a large sample size be required in order to generalize these results to the whole population.

\section{ACKNOWLEDGMENTS}

We are thankful to Dr. S. Porchelvan, MSc, MBA, PGDCA, PhD, Professor in Biostatistics for assisting with the statistical analyses.

\section{CONFLICT OF INTEREST}

The authors declare that there is no conflict of interest.

\section{AUTHORS' CONTRIBUTION}

All authors listed have made a substantial, direct and intellectual contribution to the work, and approved it for publication.

\section{FUNDING}

None.

\section{DATA AVAILABILITY}

All datasets generated or analyzed during this study are included in the manuscript.

\section{ETHICS STATEMENT}

This study was carried out in accordance with the recommendations of NIH guidelines for the Human participants and the protocol was approved by the Institutional Review Board (IRB) of the Panimalar Medical College Hospital \& Research Institute, Chennai under the protocol number: Panimalar Medical College Hospital \& Research Institute IRB \#1/2020/014. This study conformed to the requirements of the Declaration of Helsinki (as revised in Seoul 2008). All the data collected was kept confidential.

\section{REFERENCES}

1. Majumder MMI, Ahmed T, Ahmed S, Khan AR. Microbiology of Catheter Associated Urinary Tract Infection. Intech open. 2018. Accessed on June 19, 2020. doi: 10.5772 /intechopen. 80080

2. 
in Long-term Care Facilities NHSN. 2018. Accessed on June 23, 2020

3. Report on the burden of endemic health careassociated infection worldwide.WHO 2011. https:// apps.who.int/iris/handle/10665/80135. Accessed on June 24, 2020

4. Pittet $D$. Infection control and quality health care in the new millennium. Am J Infect Control. 2005;33(5):258267. Accessed on June 20, 2020. doi: 10.1016/j. ajic.2004.11.004

5. Rockville. Toolkit for Reducing CAUTI in Hospitals Agency for Healthcare Research and Quality. Accessed on June $22 / 2020$.

6. Warren JW. The catheter and urinary tract infection Med Clin North Am. 1991;75(2)481-493. Accessed on June 22, 2020. doi: 10.1016/S0025-7125(16)30465-5

7. Centers for disease Control and Prevention HICPAC Guidelines for prevention of catheter Associated Urinary Tract Infections. 2009. www.cdc.gov, Accessed on June 17, 2020.

8. Menegueti MG, Ciol MA, Bellissimo-Rodrigues F, et.al. Long-term prevention of catheter-associated urinary tract infections among critically ill patients through the implementation of an educational program and a daily checklist for maintenance of indwelling urinary catheters. Journal of Medicine. 2019; 98(8):pe14417. Accessed on Jun 23, 2020. doi: 10.1097/MD.0000000000014417

9. Nicolle LE. Catheter associated urinary tract infections. Antimicrob Resist Infect Control. 2014;(23). Accessed on June 21 2020. doi: 10.1186/2047-2994-3-23
10.

Assanga PA, Omondi AL, Inyama HK. Evaluation of the Utilization of Catheter Associated Urinary Tract Infection Bundle Among Critical Care Nurses - Kenyatta National Hospital. American Journal of Nursing Science. 2016;5(5):201-212. Accessed on Jun 21, 2020. doi: 10.11648/j.ajns.20160505.15

11. Jain M, Dogra V, Mishra B, Thakur A, Loomba PS. Knowledge and attitude of doctors and nurses regarding indication for catheterization and prevention of catheter associated urinary tract infection in a tertiary care hospital. Indian J Crit Care Med. 2015;19(2):76-81. Accessed on Jun 21, 2020. doi: 10.4103/0972-5229.151014

12. Datta P, Rani H, Chauhan R, Gombar S, ChanderJ. Healthcare associated infections: Risk factors and epidemiology from an intensive care unit in Northern India. Indian J Anaest. 2014;58(1):30-35. Accessed on Jun 21, 2020. doi: 10.4103/0019-5049.126785

13. Salha Salem Algarni, Sofar SM, Wazqar DY. Nurses' knowledge and practices toward prevention of catheter-associated urinary tract infection at King Abdulaziz University Hospital. Journal of Health, Medicine and Nursing. 2019;4(1-4):39- 62. Accessed Jun 20, 2020.

14. Parker V, Giles M, Graham L, et al. Avoiding inappropriate urinary catheter use and catheter-associated urinary tract infection a pre-post control intervention study. BMC Health Serv Res. 2017;17(1):314. Accessed on Jun 23, 2020. doi: 10.1186/s12913-017-2268-2

15. Getliffe K, Newton T. Catheter-associated urinary tract infection in primary and community health care. Age and Ageing. 2006;35(5):477-481. Accessed on Jun 23, 2020. doi: 10.1093 /ageing/afl052 